\title{
COMP Gene
}

National Cancer Institute

\section{Source}

National Cancer Institute. COMP Gene. NCI Thesaurus. Code C131262.

This gene plays a role in the structure of cartilage. 